\title{
Around the Sieve. Motif, Symbol, Hermeneutic
}

Barbara Baert

To cite this article: Barbara Baert (2018): Around the Sieve. Motif, Symbol, Hermeneutic, TEXTILE, DOI: 10.1080/14759756.2017.1413159

To link to this article: https://doi.org/10.1080/14759756.2017.1413159

Published online: 12 Jan 2018.

Submit your article to this journal

Џll Article views: 4

Q View related articles $\sqsubset$

View Crossmark data $₫$ 
Around the Sieve. Motif, Symbol, Hermeneutic 


\section{Abstract}

$T^{1}$

his article starts from the so-called sieve portraits of Queen Elizabeth I. What is the meaning of this fascinating attribute she is holding in her hand? How does this sieve relate both to her political and female identity? This brings me to a wider scope on sieves and sieving in art history and anthropology. Indeed, the sieve exhibits a wide range of symbolism that extends across art history, philosophy, ethnology, psychoanalysis, and gender studies. The article provides an interdisciplinary perspective on the sieve from three angles of approach: as motif (the sieve is an attribute), as symbol (the sieve is an image), and as hermeneutic (the sieve is a paradigm). Doing so, it will become clear that underneath the sieve the idea of textile, "textility" and texture is constantly resonating.

Keywords: sieve; sieving; Queen Elizabeth I; Tuccia; chastity; Berber; Hebrew folklore; skin-ego

\section{BARBARA BAERT}

Barbara Baert (1967) (www.illuminare.be) is Professor at the University of Leuven. Her research is situated in the field of Iconology, Art Theory, and Medieval Art. She published several books and articles, with emphasis on the role of the sensorium in the arts, on visual culture and new hermeneutical paradigmata such as Echo and Kairos, and on the past, present, and future of visual anthropology. She is the founder of the series Studies in Iconology (Peeters

Publishers) and of the annual Recollection. Experimental Reflections on Texts, Images and Ideas (University Press Leuven). In 2016 Barbara Baert was awarded with the prestigious Francqui Prize (www.francquifoundation.be) for her outstanding interdisciplinary achievements in the Bildwissenschaften, in particular and for her international impact on the Human Sciences in general.

Barbara.baertakuleuven.be
This essay is the prelude of a larger book project, "About Sieves and Sieving. Motif, Symbol, Technique, Paradigm." In this forthcoming book (2018-2019), the author, Professor Barbara Baert discuss in more detail the Sieve Portraits of Elizabeth I from the point of view of her ambivalent sexual/virgin status in intellectual history. By having herself depicted as a new Tuccia, the queen demonstrated her familiarity with humanist iconographic conventions of chastity. Professor Baert is currently planning a further chapter-length text on the impact of the sieve and new methodologies, including how sieves/sieving might offer an alternative hermeneutical gaze in the Human Sciences, and in particular in ethnology, gender, literary studies, and the analysis of "framing spaces."
Textile

DOI: $10.1080 / 14759756.2017 .1413159$

(D) Check for updates

(C) 2017 Informa UK Limited, trading as Taylor \& Francis Group 


\section{Around the Sieve. Motif, Symbol, Hermeneutic}

The primary aspect of the schizophrenic body is that it is a sort of body-sieve. (Deleuze 1990, 87)

\section{Introduction}

The subject of this article is the motif of the sieve-Sieb (German), tamis (French), zeef (Dutch), setaccio (Italian), tamiz (Spanish). The sieve exhibits a wide range of symbolism that extends across art history, philosophy, anthropology, psychoanalysis, and gender studies. This paper will provide an interdisciplinary perspective on the sieve from three angles of approach: as motif (the sieve is an attribute), as symbol (the sieve is an image), and as hermeneutic (the sieve is a paradigm).

The sieve as attribute goes back to Roman stories of the Vestal virgins. The Vestals Aemilia and Tuccia, suspected of being unchaste, were able to prove their innocence by collecting water from the Tiber in a sieve and carrying it into the city without spilling a drop. The (impermeable) sieve thus became an important epitheton for chastity, and was iconographically transferred to contemporary women. In a famous series of portraits, Queen Elizabeth I (1533-1603), for example, is shown with a sieve as a sign of her integrity.

The second part explores the longue durée of the sieve as a symbolic object of use, looking at examples from Jewish folklore, Berber culture, and ancient Egypt that indicate the cosmological impor- tance of the action of sifting, and the exclusivity of women in the related actions. The roundness of the sieve and the "shaking," rocking, circular movements support this symbolic spectrum. Female responsibility for nutrition and hygiene are cultically and symbolically transferred to the sieve.

The third part considers the sieve's hermeneutic relevance as "textility" and as skin-ego (moipeau). This relevance already begins with its tectonics. The sieve's filtration process is made possible by a woven structure, often utilizing natural materials, such as horsehair and types of grass. Its capacity in a single action both to retain (saving the good) and to remove (discarding the unwanted) makes the sieve a fundamental symbol of "separation" and "filtration." The sieve separates like a membrane, a dripping filter. This makes the sieve a fruitful image for the skin, with its pores, but also for the role of the unconscious that seeps through according to rules of its own (moi-peau).

\section{The Queen, the Portrait and the \\ Sieve}

The "sieve portraits" of Queen Elizabeth I of England and Ireland (1533-1603), including the wellknown Plimpton Sieve Portrait (1579) and the Siena Sieve Portrait (c. 1583), were created between 1570 and 1580 (Connolly and Hopkins 2007; Erickson and Hulse 2000; Hart 2008). The Plimpton Sieve Portrait of 1579 is attributed to George 


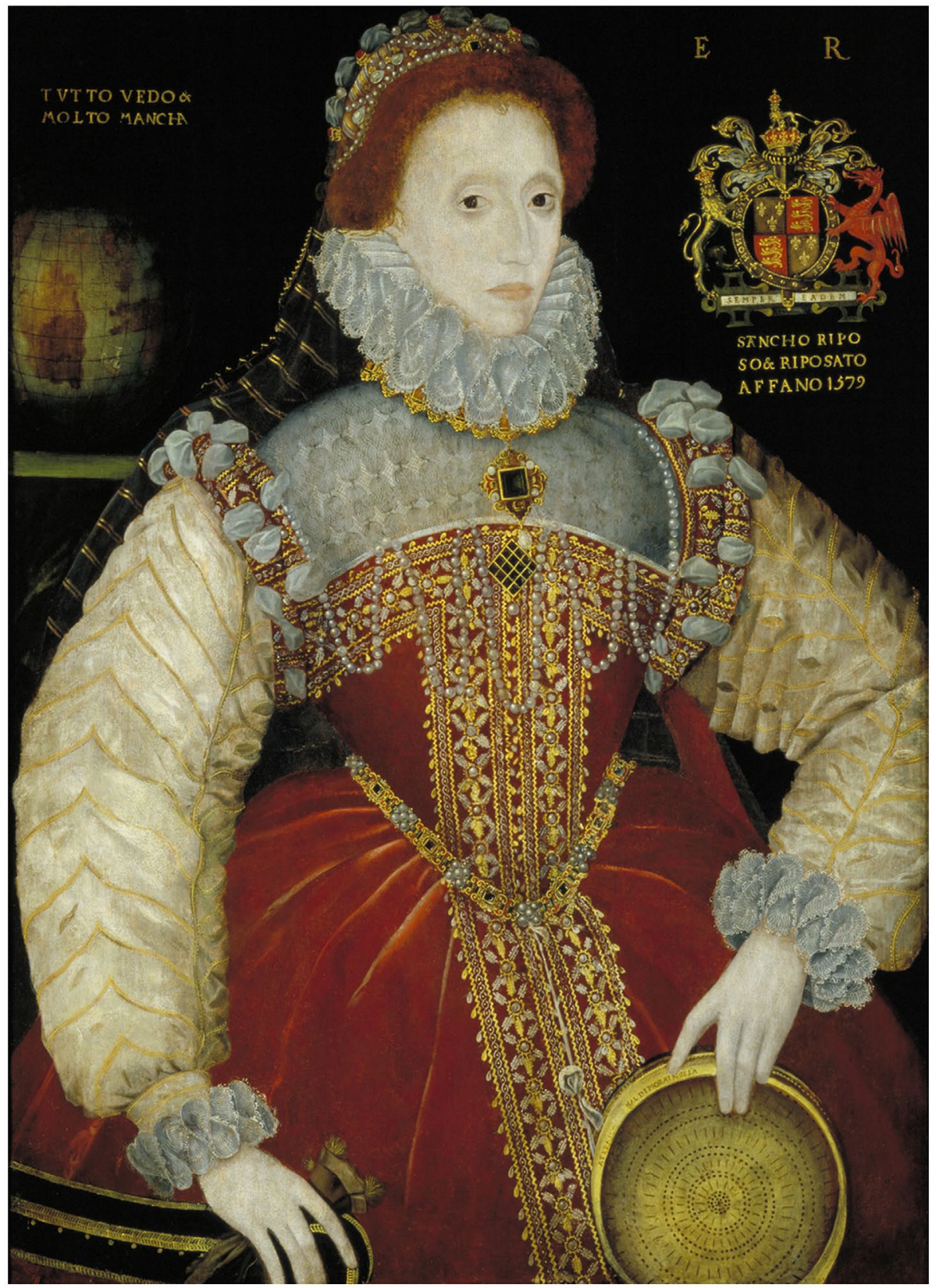

Figure 1

George Gower (c. 1540-1596), The Plimpton Sieve Portrait of Elizabeth I of England, 1579. Oil on panel, $104.4 \mathrm{~cm} \times 76.2 \mathrm{~cm}$. Folger Shakespeare Library, Washington, D.C., inv. no. ART 246171.

Gower (1540-1596) (Figure 1). The Siena Sieve Portrait is attributed to Quentin Metsys the Younger
(1543-1589) (Figure 2). Both portraits were painted in a period of fraught negotiations concerning a possible marriage to Francis, Duke of Anjou (1555-1584). ${ }^{1}$ The queen remained unmarried, however, and 


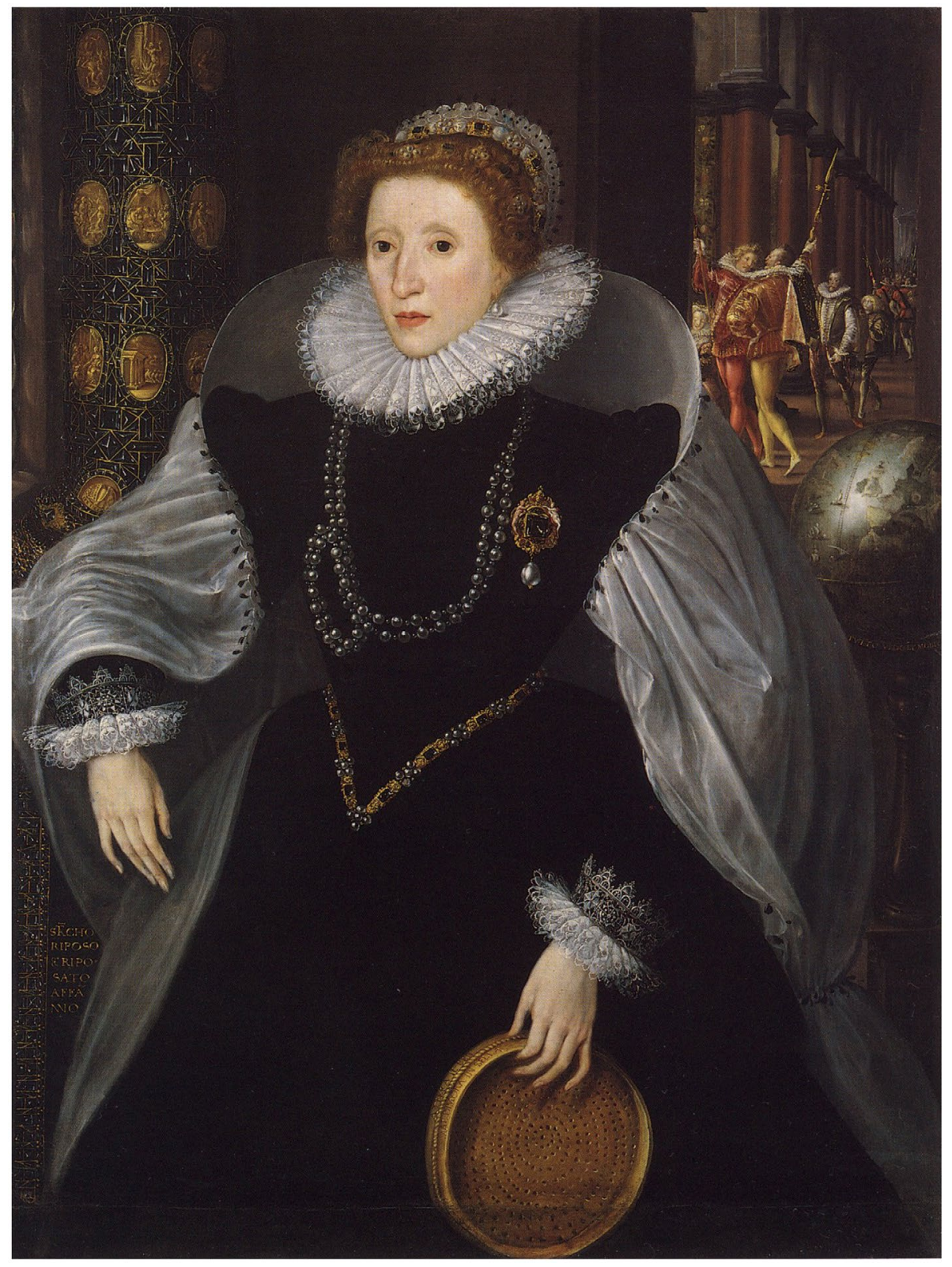

Figure 2

Quentin Metsys the Younger (c. 1543-1589), Sieve Portrait of Queen Elizabeth I (Siena Sieve Portrait), 1583. Oil on panel, 124.5 x $91.5 \mathrm{~cm}$. Pinacoteca Nazionale, Siena, inv. no. 454.

was given the epithet of Maiden Queen or Virgin Queen. This is the context in which the attribute of the sieve should be read. It will be argued below that the queen-virgin was positioning herself as a contemporary Vestal virgin.
In the Plimpton Sieve Portrait, Elizabeth holds a round sieve in her left hand. In the left corner behind the queen a globe can be seen. The 
roundness of the sieve reflects the shape and position of the globe. But while the globe is a conventional motif in the iconography of imperial portraits, the sieve is a peculiar choice for the genre. The sieve is attached to the queen's clothing with a cord and buckle, becoming an extension of her body.

The sieve is a profane object from the personal space of female household equipment. In the pictorial space of a dynastic portrait, the sieve becomes an attribute with symbolic meaning. This is apparent from the motto in the Plimpton Sieve Portrait, a quotation from the Trionfo d'amore of Petrarch (1304-1374): "wearied rest and rested weariness" [stancho riposo e riposato affano] (Williams 2006, 49-51). "Here, an emblem of discernment, more than tumescence, provides the key image of political power," writes Deanne Williams (Williams 2006, 49). The sieve that separates good from evil is, after all, also a symbol of government, as can be seen from the second motto written on the globe: "I see everything but much is lacking" [tutto vedo e multo mancha].

The Siena Sieve Portrait similarly shows a sieve and a globe, but this portrait also has a gallery in the background with the story of Aeneas and Dido, another allusion to Elizabeth's ideal of chastity.

The pillar to Elizabeth's right depicts scenes from the Aeneid: Dido's first meeting with Aeneas at Juno's temple, their idylls in the cave, and, ultimately, Dido's self-immolation. These are images of Dido the sensualist, Dido the seduced. They provide visual reminders of the stings of love and eros that Elizabeth has repudiated for herself, and on her country's behalf. ${ }^{2}$ (Williams 2006, 41)

Ancient literature developed the sieve as a symbol for chastity. In his Factorum et dictorum memorabilium, Valerius Maximus (first century AD) tells the story of the Vestal Tuccia who was accused of being unchaste. As proof of her innocence Tuccia scooped water from the Tiber with a sieve and carried it to the temple of the Vestals without losing a drop (Shackleton Bailey 2000, 193). ${ }^{3}$ Tuccia's impermeable sieve is naturally a paradox. The anomaly in the Tuccia story articulates the woman as water that is retained, as an impermeable and therefore untouched hymen. The sieve now becomes a receptacle, a water pitcher.

Christianity also adopted the Vestal virgin's unusual ordeal as an image of chastity. This marvel could, furthermore, be linked to the sealed jar, or vas, as a symbol of Mary. Mary is the honorabile vas that preserves the divine child. In the same vein, the baptismal font is the venter ecclesiae (Lurker 1991, 232-233; Neumann 1957, 51, 123-146). In the Song of Songs (7:2) we read "Thy navel is like a round goblet," and according to Hildegard of Bingen (1098-1179) the female is the vas viri. ${ }^{4}$

Augustine (354-430) twice refers to the story in his De civitate Dei (Dyson 1998, 416 (10.16.2)). Petrarch's Triumph of Chastity also refers to Tuccia, alongside Lucretia, Penelope, Virginia, and Judith (Baskins 1999, 15-25). Leon Battista Alberti (1404-1472) uses Tuccia's proof of chastity as an exemplum in his treatise Della Famiglia (c. 14331434), stating (paraphrased) that nothing is as important for a woman or as good in the eyes of God, as pleasant in the eyes of the man or as precious to the child as chastity (Alberti 1969, 113). "Her chastity is a jewel for the family and greater than her beauty." In the Italian Quattrocento the story of Tuccia was therefore a popular iconographic theme on wedding chests and christening chests, and on wood panelling in

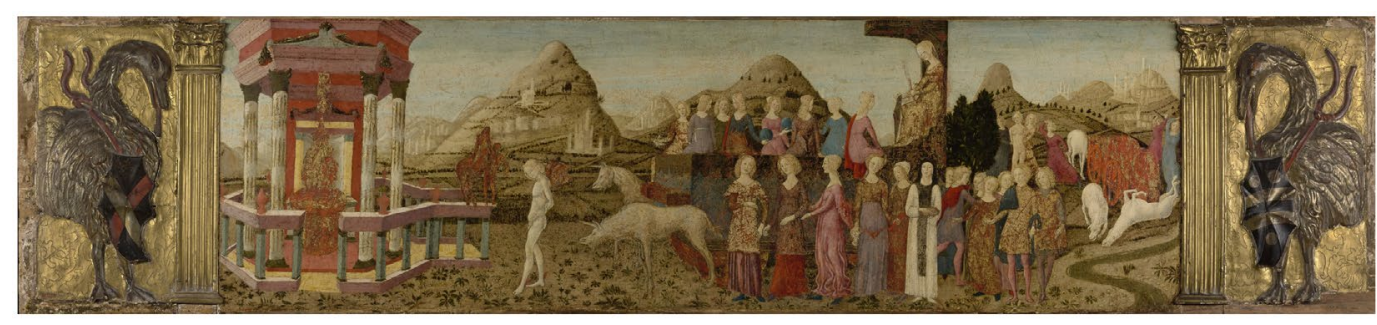

Figure 3

Francesco di Giorgio Martini, The Triumph of Chastity, c. 1463-1468. Tempera on panel, $38.7 \mathrm{~cm} \times 170.4 \mathrm{~cm}$. J. Paul Getty Museum, Los Angeles, inv. no. 57.PB.2. 


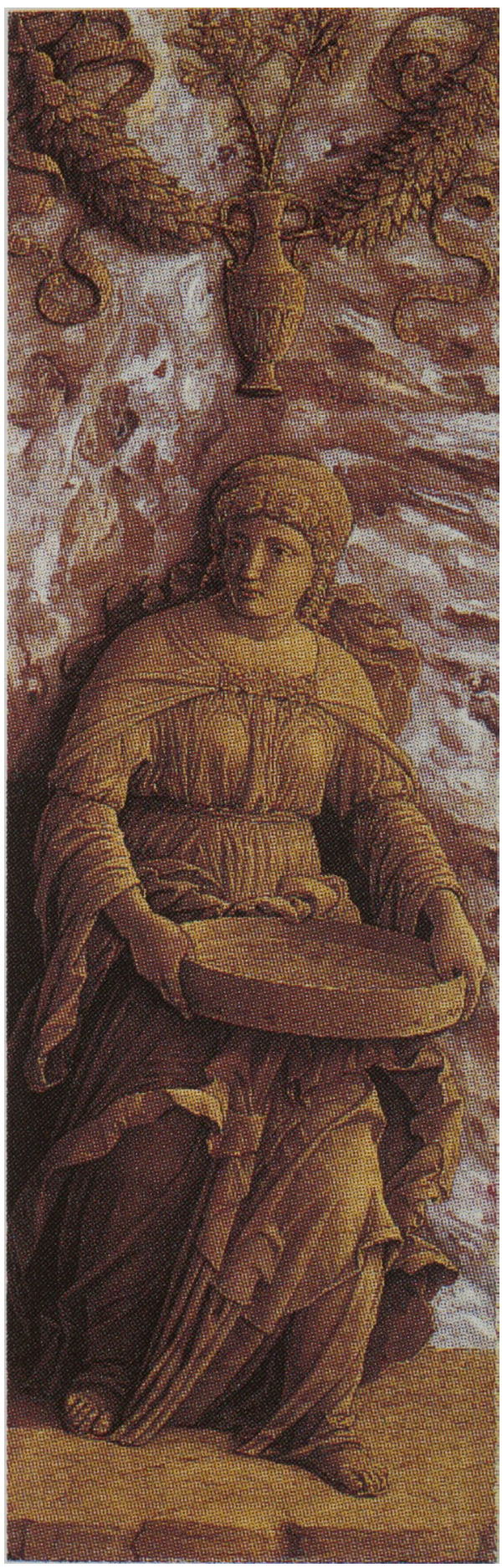

Figure 4

Andrea Mantegna (1430/31-1506), Tuccia, c. 1495-1506. Tempera on poplar, $72.5 \mathrm{~cm}$ x $23 \mathrm{~cm}$. National Gallery, London, inv. no. NG1125.1. 


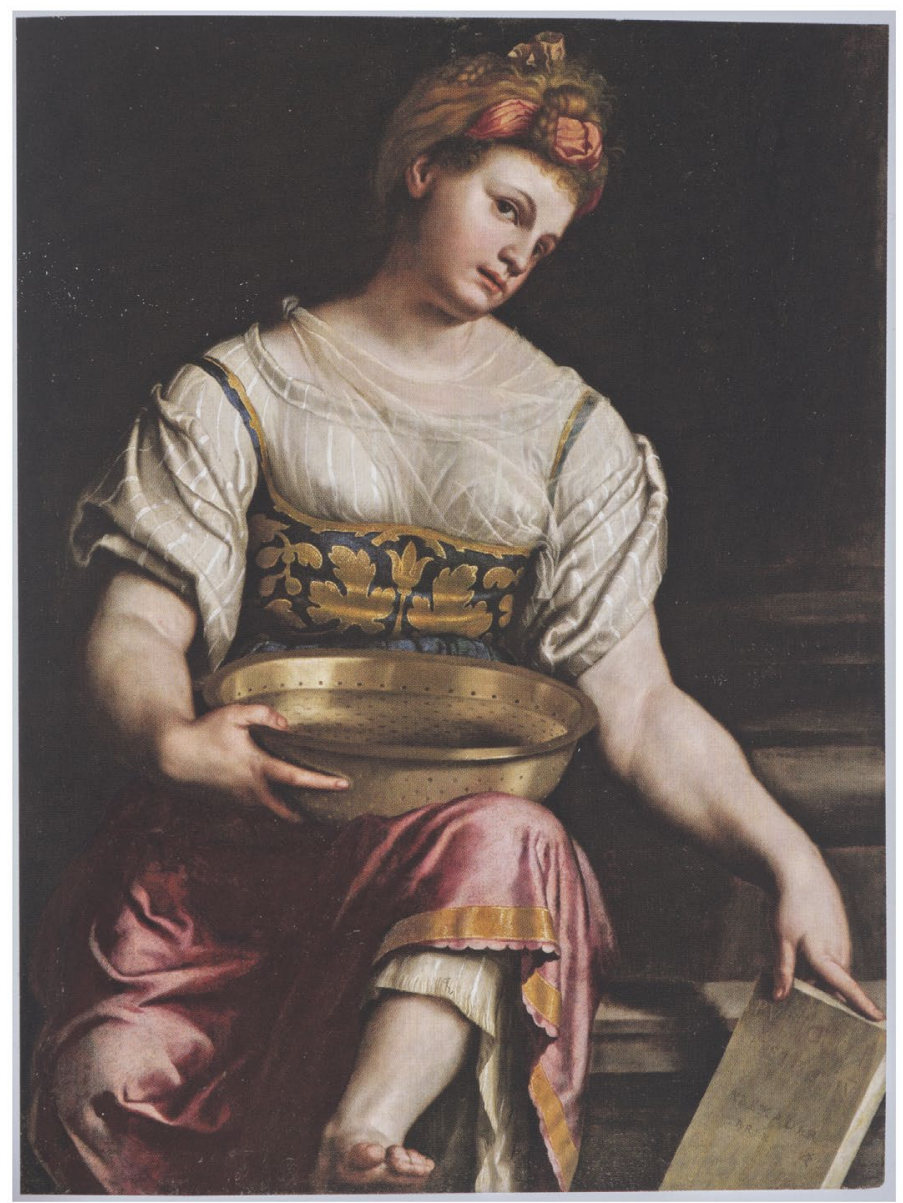

Figure 5

Moretto da Brescia (Alessandro Bonvicino) (c. 1498-1554), Tuccia the Vestal, c. 1540-1544. Oil on panel, $113 \mathrm{~cm} \times 86 \mathrm{~cm}$. Private collection, New York.

female private spaces (Figure 3)

(Miziolek 2001, 72-88).

The four grisaille panels by Andrea Mantegna (1431-1506) showing Tuccia and Sophonisba (now in the National Gallery, London), and Judith and Juno (now in the Museum of Fine Arts, Montreal), were once part of a Trionfo della virtù ensemble for the private studio in Mantua (Figure 4) of Isabella d'Este (1474-1539). ${ }^{5}$ Isabella d'Este's famed expression "our insatiable desire for ancient things" [Lo insaciabile desiderio nostro de cose antique] also refers to her intellectual affinity with ancient knowledge and her desire to mirror herself on the virtuous heroism of these four women (see also: Tuve 1963). We know of other paintings regarding this humanistic female exemplarism. In her catalog Art and Love in Renaissance Italy, Andrea Bayer refers to an interesting painting (c. 1540-1544) by Moretto da Brescia (1498-1554), ${ }^{6}$ in a private collection in New York, on which the
Vestal Tuccia is presented as a contemporary woman holding a sieve in one hand (Figure 5) (Bayer 2008, 313-314). Her other hand points to a tablet that reads: "In proof of her chastity" [Pvdicitiae / testimoniv alexader (sic) / brix.F].

In the sieve portraits of Elizabeth the Italian tradition is radicalized further. By having herself depicted as a new Tuccia, Elizabeth in the first place demonstrated her familiarity with humanist iconographic conventions of chastity. The sieve 
of chastity was at that time also familiar in the emblem literature produced for elite readers, such as Geffrey Whitney's 1586 work (Montrose 2006, 121-127; Fig. 34; Whitney 1586, 68).7 By inscribing herself as head of state in this tradition, Elizabeth furthermore raised a tension between the ideal of feminine chastity in general, and the standard of chastity that, as queen, she in particular publicly set. In other words, this portrait doubly stages Elizabeth as Tuccia, since she had two bodies: one in private space and one in public space.

Louis Montrose writes: "The sieve constitutes a displacement of the Queen's sexuality. The interpretative question concerns how that sexuality is being symbolized in the sieve" (Montrose 2006, 124; see also: Strong 1987, 96).

The sieve is a paradoxical 'heroicall devise' uniquely appropriate to a virgin queen whose realm is a virgin ruler and a prospective royal bride. The sieve portraits are not merely celebrations of royal chastity; they are compelling icons of Elizabethan eroto-politics, as these were played out both within the ambiance of the court and upon the global stage. (Montrose 2006, 127; see also: Adler 1978, 1-10)

To which Susan P. Cerasano and Marion Wynne-Davies add:

In a society whose hierarchy offered absolute privilege to men, the ideological shift required to accept a female ruler was considerable, if not impossible. Thus the conventional view of women which focused upon their containment within a private world had somehow to coexist with the reality of the public show necessary for a monarch. Elizabeth I was without doubt, a female ruler accepted by her contemporaries because of her own exceptional qualities; they condoned the individual, not the concept of female majesty. But the same byplay between private and public selves does occur repeatedly in the representations and writings of other renaissance women. (Cerasano and WynneDavies 1992, 2)

In brief, "The association of Elizabeth with Tuccia's sieve serves to separate her from womankind as a whole-and thus from the contradictions of a woman ruler" (Paster $1993,50)$. In the sieve portraits both bodies are combined and to a certain extent intermixed, resulting in an ambivalent message, making Elizabeth unique in her female gender and in her royal choice to remain a maid (Hazard 1990, 79). ${ }^{8}$ Georgianna Ziegler put it as follows:

While her chastity and business are praised by renaissance men in their various representations of her for the benefit of women, it is also true that as a woman she asserts power over her own body with her conscious decision to remain chaste by repulsing the advances made to her by men. (Ziegler 1992, 40)

In this regard the enigmatic words of Elizabeth herself bear repetition: "I am not; I freeze and yet am burn'd; / Since from myself, my other self I turn'd."9 (Cerasano and Wynne-Davies 1992, 8). These verses suggest her wrestling with the ambivalence of being both desiring woman and public figure. Perhaps the poem indicates a "'regret' of a poignantly painful paradox, an acute awareness of a double self" (Cerasano and Wynne-Davies 1992, 8). The sieve too is binary, a "double self," for it retains to remove: it is always a choice with loss.

In the following section I will look more deeply at the sieve's range of symbolic connotation, since ancient times situated in private female space.

\section{Etymology, Symbolism and longue durée}

The prehistoric, proto-Indo-European word for sieve has been reconstructed as kreidhrom-giving cribrum in Latin and kroskinon in ancient Greek - meaning sifting or sieving substances, but also by transference "to distinguish," and to reach a decision (cerno in Latin, krino in Greek) (Adams 1997b, 518). It is assumed that the stem relates to sifting dry materials, such as grain, rather than liquids, such as dairy products. In any case the idea of purity is closely related to this Indo-European etymology, as is apparent from the stem peuh, meaning sieved, sifted, which gives the Latin purus: purified, fresh, spotless (Adams 1997a, 108-109).

The second oldest Indo-European root for sieve is sehj, which can be seen in the Latin sinus and

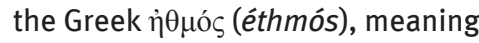
globular, hollow. Sehj is related to sei sif-/sib and sē(i)-, sei-, meaning to drip, as in the Serbian sípiti: to drizzle (Philippa et al. 2003-2009). Even in Sumerian the stem sig underlies a semantic complex that touches on rain, pouring oneself out, and pouring through a sieve.

The third root for the sieve is reh-, which primarily in Baltic languages is closely related to a "net" for hunting and for fishing 
(rete- in Latin). Here the sieve connects to the primordial techniques of weaving and of a grid pattern. ${ }^{10}$ The same connotations can be found in Hebrew. The two words for sieve are kebarah and naphah. Kebarah derives from the stem kabir: something woven, like a cloth or a net, as in the Arabic ghurbal. Naphah comes from nuph: to move back and forth, to cradle, to sprinkle. Naphah furthermore can also mean border, region, shoreline.

The notions of separation, purification, seeping through (raining), shaking, and the technicity of the "net," point to the primordial capacity of the sieve both to let through and to hold back. Sifting is an action that aims to keep a clean residue while discarding waste. It is also a means of separating coarser from finer parts (Philippa et al. 2003-2009). The sieve is a basic tool through which humans interact with their environment and in particular with the substances needed for nutrition, hygiene, and wellbeing (Figure 6). ${ }^{11}$

As has been mentioned, sieves have existed since the Neolithic. Archaeological finds from biblical times indicate that grain sieves, at least, were relatively large, about $90 \mathrm{~cm}$ across, with a $20 \mathrm{~cm}$ high wooden side. ${ }^{12}$ The mesh was mostly made of woven grass or very finely interwoven twigs. Little was written about sifting as such in ancient cultures, probably because it was so ordinary. It is thought that the sifting process changed little. This makes the descriptions in James Neil's Peeps into Palestine (c. 1915) particularly illuminating with regard to the biblical Mediterranean area. He writes:

The process ... has never to my knowledge been described by any previous writer ... The woman servant-for it is only women who siftsets herself on the ground with her feet spread widely apart, taking in her hands a large but shallow sieve called ghurbal [supra], some two and a half feet across.
Having placed a small amount of wheat in the ghurbal, or sieve, she commences by giving it some six or seven sharp shakes, so as to bring the chaff and short pieces of crushed straw to the surface, the greater part of which she removes with her hands. After this the main part of the work begins, which is done with much skill. Holding the sieve in a slanting position, she jerks it up and down for a length of time, blowing across the top of it all the while with great force. In a word, she turns herself into a regular winnowing machine! Three results follow. In the first place the dust, earth, small seeds, and small, imperfect grains of wheat, etc., fall away through the meshes of the sieve. Secondly, by means of the vigorous blowing, any crushed straw, chaff, and such-like light refuse is either blown away to the ground, or else collected in the part of the ghurbal which is furthest from her. Thirdly, the good wheat goes together in one heap about the center of the sieve, while the tiny stones or pebbles are brought into a separate little pile

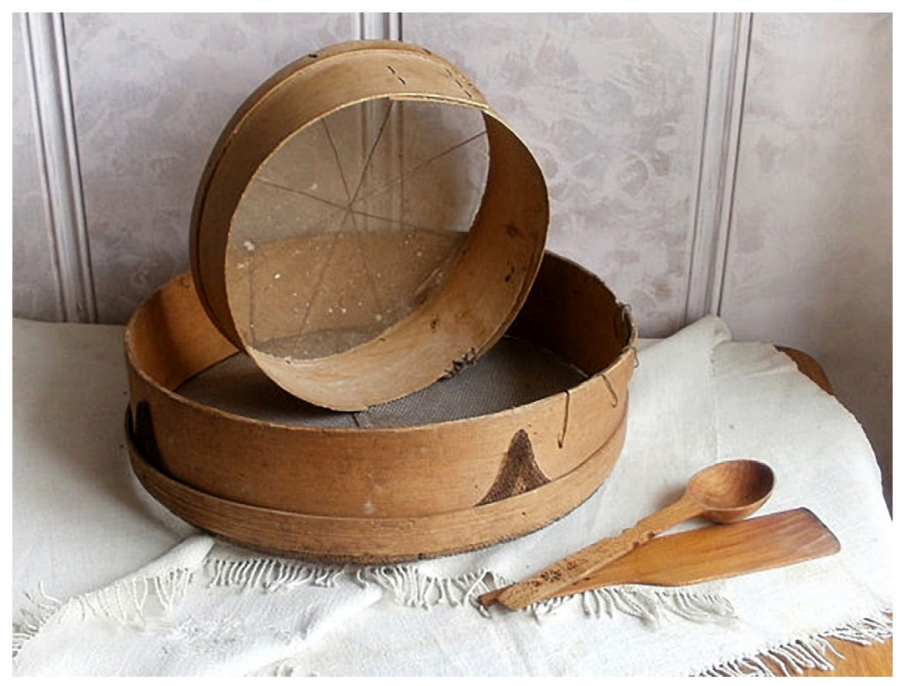

Figure 6

Household set of sieves from Ukraine, around 1930. 
on that part of it which is nearest to her chest. The pebbles, chaff, and crushed straw thus cleverly removed from the corn [grain], mainly by the angle at which the sieve is held and the way in which it is jerked up and down, are then taken out of the ghurbal with her hands. Finally, setting the sieve down upon her lap, she carefully picks out with her finger any slight impurities which may yet remain, and the elaborate and searching process of sifting is complete. (Neil, c. 1915, 58-59)

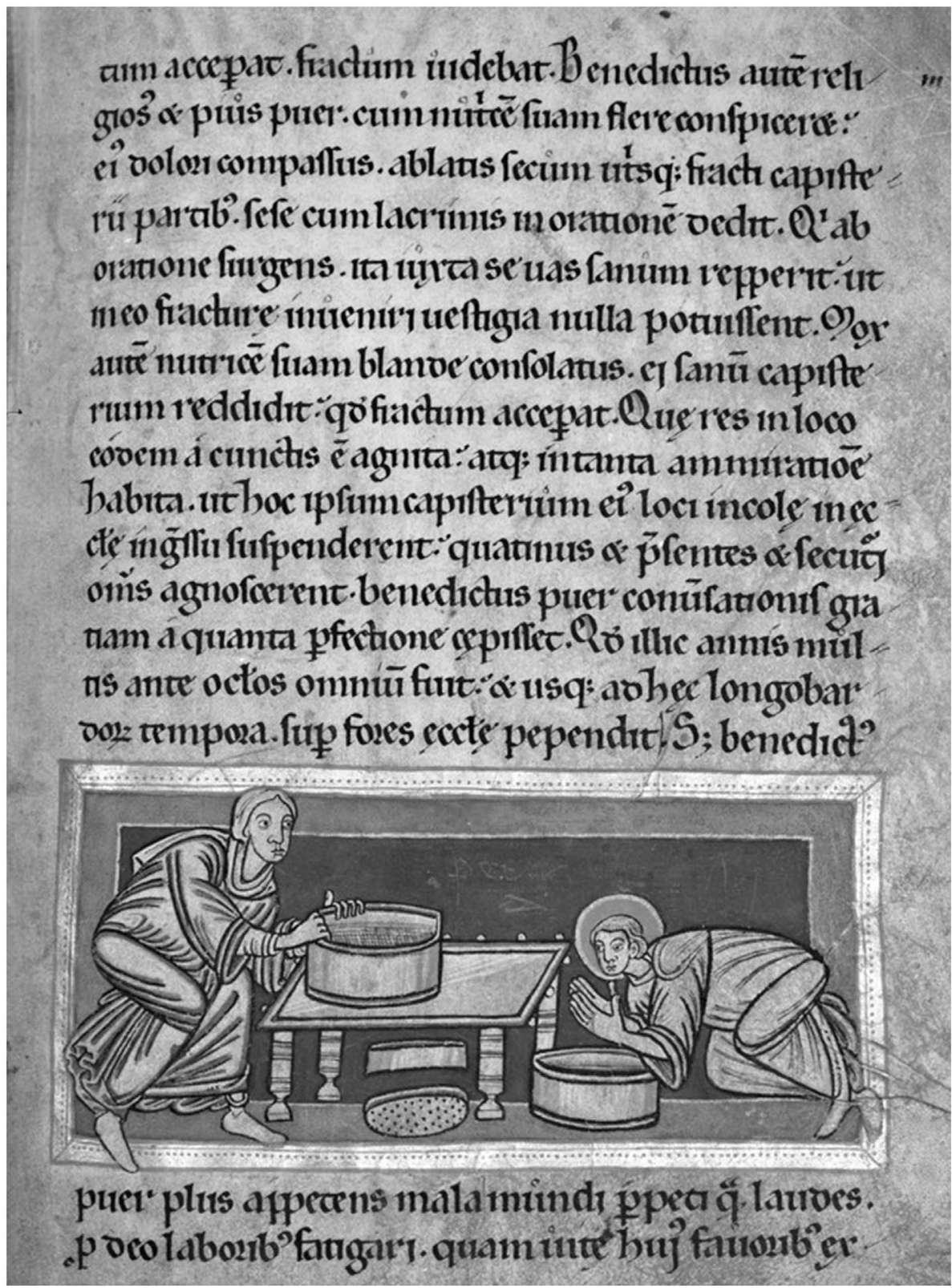

Figure 7

St Benedict repairs his nurse's sieve (detail), Gregorius Magnus, Dialogi, 1156-1175. Royal Library of Belgium, Brussels, Ms .9916-17i, fol. 30r. 
This sheds light on Amos 9:9, “For I will give the command, and I will shake the house of Israel among all the nations as grain is shaken in a sieve, and not a pebble will reach the ground." This ancient sieving technique separates the grain from the pebbles, but the pebbles remain in the sieve. The translators of the King James Version, familiar with more modern processes of filtration, could not understand this and produced: "For, lo, I will command, and I will sift the house of Israel among all nations, like as corn is sifted in a sieve, yet shall not the least grain [rather than pebble] fall upon the earth." Another instance of ancient sifting technique can be found in Luke 22:31-32 (English Standard Version): "Simon, Simon, behold, Satan demanded to have you, that he might sift you like wheat, but I have prayed for you that your faith may not fail." Grain would at that time be bought with all sorts of dirt and extraneous matter. Sifting made the larger waste visible (rather than removing it as such), so that it could later be removed by hand.

In his Dialogues, Gregory the Great (died 604) recounts the story of the sieve mended by Benedict of Nursia (Norcia) (480-547) (Blum 1981, 76; Moricca 1924, 71-75). Benedict was traveling out of Rome to Effide (now Affile) in Abruzzi, in the company of a nun. They found lodgings for the night near the village's church of St Peter. The nun placed her sieve for cleaning grain too far over the edge of the table, so that it broke. She was very distressed about this, particularly as she had borrowed the sieve from a neighbor. Benedict, moved by her tears, withdrew to pray. By his prayers the sieve was miraculously made whole. This was the first of 12 miracles worked through Benedict. The sieve was afterwards hung over the doorpost of the church of St Peter, where it continued to be the locus of a series of miracles.

This passage shows the relationship between the feminine intimate space of the household and the intimate zone of the sieve that must remain "intact." The broken sieve is an image of the loss of female integrity and in this case the nun's religious purity. Gregory refers to the sieve by the terms capisterium and vas indifferently (without using cribrum). Du Cange's Glossarium mediae et infimae Latinitatis specifies that a capisterium is a bowl used to cleanse grains (Du Cange 1954, 129). ${ }^{13}$ They were generally wooden, and could vary a great deal in shape. In the thirteenth-century manuscript with the Dialogues preserved in the Royal Library of Belgium, the capisterium is a large bowl-shaped sieve (Figure 7). On the left the nun is shown at the table with the sieve, on the right Benedict kneels over the sieve. In the middle is the broken sieve: the filter has come loose from the frame.

In the miracle story the sieve ultimately becomes part of the community: it is exhibited at the church door to protect the village. Because what remains in the sieve is "pure," the sieve is indeed an apotropaion, an instrument to ward off evil (Eckstein 1936, 1662-1701). Into the seventeenth century there are details of "sieve magic" or "coscinomancy" as ways of predicting the future by turning a sieve, ${ }^{14}$ playing it like a drum, or holding it up to the sun for a good harvest (Brewer 2001, 999; Lilek 1896, 61; Róheim 1951, 136, $137,164)$. The sieve is also a motif in fairy tales. Between twelve o'clock and one, Frau Holle carries water in a vessel without a base, a wonder comparable to tales of Vestal virgins. In all sorts of North German stories witches and stepmothers command girls to carry water in a sieve. Weather witches also carry a sieve as an attribute (Eckstein 1936, 1668; Zysk 1985, 62). In Finland the goddess Uutar was thought to cast the rain from the clouds with a gigantic sieve.

Because the sieve purifies milk and separates grain, it is also an important symbol of fertility. Even the posture when sifting grain is suggestive of giving birth, as we learned from Neil's descriptions: "The woman servant-for it is only women who sift-sets herself on the ground with her feet spread widely apart, taking in her hands a large but shallow sieve called ghurbal, some two and a half feet across." Raphael Patai devotes a chapter of his On Jewish Folklore to the role of the sieve in old Jewish fertility rites (Patai 1983, 387-388). Among Bedouin tribes, as well as among Jews in the Caucasus, it is still customary to catch a child being born in a sieve (Patai 1983, 387). In Egypt too newborns were laid in a grain sieve, and into the nineteenth century it was customary to "shake" the child in the sieve on the seventh day, supposedly as a way of promoting good digestion. The same custom can be found in Andjra in Morocco, where on the seventh day the child is laid in a sieve with henna, an egg and a bowl of water. In Tangier a sieve is shaken above the head of a newborn boy whose brother has died (but not a girl, for then she would never marry). 
Such customs of laying newborn children in a sieve and shaking them is an extension of the idea that the child will benefit from actions that mirror certain preparatory techniques from the woman's kitchen. They can be explained from archetypal association between the child and grain or bread, between the womb and the fertility of the earth, and also between sifting grain / kneading bread / baking bread and conceiving / making / bearing / caring for a child.

Patai sees in the sieve parallels to the bed, the cradle, the crib, all of which have a chthonic relationship to the inner bosom of the earth. Although this association is not found word for word in the Bible, the word arisa is used for a kneading trough in Numbers 15:20-21 and in Nehemiah 10:37, while in the Talmud the same word is used to mean a cot or cradle (Patai 1983, 388). The cradle can be shaken or rocked (compare the etymology of sieve as naphah) just as bread can be kneaded. The movements that the sieve, the cradle, the kneading trough, and the crib elicit are spontaneous motions that recur in various feminine domains of care, hygiene, and preparation, and consequently cover a wide spectrum of engagement with the intimate setting.

The strong relationship between the sieve and the exclusive intimate zone of the woman in the household and the activity of childbirth makes the sieve a cosmogonic symbol (Jones 1989, 205). ${ }^{15}$ Among Berber women in Kabylia, for example, the sieve is linked to the grain mill. The upper and lower stone that grind the grain with circular movements to left and right symbolize the cosmos (Makilam 2007, 73-75).
There is however an important difference with the sieve, which in these female communities is always moved from right to left, because sifting symbolizes a movement "towards the stars," and does not copy the movement "of the stars" themselves. Among the Berbers, the sieve may on no condition leave the house, and as a cleansing object it must itself be kept clean at all times. In Kabylia there is a story of an evil woman who deliberately turned the sieve in the opposite direction to disrupt the luck of others, and then hung the "widdershins" sieve outside above her doorway (compare the legend of St Benedict of Nursia), in order to infect others with the evil. The story indicates the great power of the sieve and the misuse that can attend it (see also: Popov 1989, 29, 54, 59, 83 for comparable stories that circulated among the Bulgars).

The wondrous cosmogonic energy that emanates from the sieve in the female environment of food, procreation, protection, and care resides in the essence of the sieve itself as a permeable membrane that brings cleanness and separates the desired foodstuff from contaminants. This makes the sieve a membrane of life comparable to the amnion, the amniotic sac that surrounds a baby (King 1986, 117-126). ${ }^{16}$ In Egyptian hieroglyphs the sieve stands for the consonant $k h$. The sieve means the placenta that filters the baby's nutrition. In Egyptian alchemy this hieroglyph is also the pictogram for the combining of particular substances into a unity and a higher synthesis. Figuratively, the $k h$ sieve signifies the process of the soul's self-perfection (Cirlot 2001, 296).
The Egyptian deity Anubis is sometimes shown with the sieve as a symbol of the moon (Ritner 1985, 151). The Persian epic myth of Amirani recounts about the hero who was swallowed by a dragon and was able to make his way out of its stomach. However, he took the precaution of placing a wooden sieve in the opening, just in case the dragon ever swallowed the sun (an image of the solar eclipse) (Abrahamian 2007, 94-95). Should that happen, the sun could burn through the fine mesh of the sieve and free itself. Looked at more closely, this liberation of the sun is a rebirth through the membrane of the womb and the "belly" of the underworld that the dragon symbolizes.

A final important symbolic use of the sieve takes place in ritual therapeutic dance and music. Because the sieve was often stretched animal skin, such as the horsehide used by Romanians and Hungarians, the sieve could also be used as a drum or a tambourine (Róheim 1951, 136, 137, 164). László Kürti devoted an extensive study to the Shamanic connection, surviving well into the nineteenth century in the Hungarian countryside, between horse, sieve, and drum (Kürti 2007). The rhythmic galloping of the horse is repetitively linked to the horsehide sieve-drum. The rhythm supported two basic forms of dance: the circular dance (usually feminine, incorporating the sifting action of rocking and circling) and what is known as "hopping," a trampling of the ground with the feet (usually masculine, incorporating the sifting movement of shaking and scattering).

The gender distinction is mirrored in the Hebrew use of rqd for the masculine dance, and $h w l$ 
for feminine (Ilan 2003, 136). Rqd refers to jumping up and down and is also used in the context of a ship bobbing up and down on the waves, as well as for the jumping of the contents of the sieve when sifting. $H w l$ is the circle dance and the stem returns in circular motion and round household objects such as the sieve.

Circling, rocking, and shaking are therapeutic body movements that have recognizable counterparts in the natural and cosmic environment (see also: Baert 2016a). ${ }^{17}$ The sieve is charged with these hierophantic and divinatory energies. It is therefore fitting to end this section with the reflections of Bettina L. Knapp:

Circling and circular images also come to the fore in the opening whirlwind image. Circular movement around a center not only focuses energy, but relates to the idea of 'circulation' thereby generating energy and activity and beginning of course of action. Let us recall that Yahweh directed Joshua, in his conquest of Jericho, to 'compass the city ... and go round about the city ...' (Josh 6:3). Circles and circlings also suggest an absence of divisiveness and of distinction: something eternal and immutable, without beginning or end. ... The circle, as it appears and disappears amid the swirling wind, the coiling eddies, and the particles of sand, also had a mandala effect. ... Only when the turbulence dies down can energy be concentrated on a given area and fragmentation cease, thereby divesting the brain of extraneous matter, idle thoughts, and random feelings. Since a mandala actualizes cosmic energy, it may also be looked upon as a microcosm of divine power, thereby taking on the contours of a sacred space and interiorizing the energies within its sphere. (Knapp 1990, 60-61)

The round sieve, its penetrability and filtering stimulated in repetitive dance-like up-casting motions, becomes an image of flaming up, but also of coming to rest, of removing ballast, but also of isolating what is beneficial. The following section will explore the unique combination of objectness (membrane) and functionality (agency).

\section{From Textility to Skin-Ego. Four Hermeneutic Statements}

The sieve is a Kulturtechnikobjekt par excellence (term borrowed from Siegert 2015). The sieve not only filters human necessities; in doing so it is a filter between itself and the environment in which mediation and permeability articulate cognitive and tactile contact with the world, just as the word krinein, a critical sense of discrimination, is part of the Indo-European core vocabulary. Jean Chevalier and Alain Gheerbrant put this succinctly:

Image of selection, of criticism, of the screen, the sieve is one of the symbols of separation. ... decisions to be made, decisions to undergo. The ambivalence of the symbol gives rise to the same anguish: that of rejecting one thousand grains one loves to retain only the best, or that of being rejected with the thousand and not retained as the best. The sieve also symbolizes the discretionary generosity of the gods, who spread from heaven gifts in profusion, but without taking into account the prayers, sacrifices, and merits. [Image de la sélection, de la critique, du crible, le tamis est un des symboles de la séparation. ... décisions à prendre, décisions à subir. L'ambivalence du symbole engendre la même angoisse: celle de rejeter mille grains qu'on aime pour ne retenir que le meilleur, ou celle d'être rejeté avec les mille et non retenu comme le meilleur. Le tamis symbolise également la munificence discrétionnaire des dieux, qui répandent du haut du ciel des dons à profusion, mais non sans tenir compte des prières des sacrifices et des mérites.] (Chevalier and Gheerbrant 1982, 921-922)

Its essential characteristic of "separation" makes the sieve both a relative and a dominant instrument. Relative, because the sieve can only separate and purify what a human has designed it to deal with. Dominant, because the sieve is always effective. This relativity, but at the same time the sieve's cruelty and inescapability-it "always" throws something away-make it an agent of "exclusion" and thus in a sense of discrimination. The sieve derives its nature from the binary, separating the undesirable refuse from the desired residue, thus placing it "opposition" to models of thought that seek to embrace cohesion, uncertainty, intermixture, and intuition.

This section will set out some anthropological, philosophical, and psychoanalytical frameworks that will help us to understand the sieve as a paradigm. Working from Tim Ingold's "textilities and tectonics" and Rosalind Krauss's theory of the lozenge, through Didier Anzieu's moi-peau, to Ernst Fischer's "uncanny space," I focus on four statements. The sieve as textility and tectonics. The sieve as grid. The sieve as moi-peau. The sieve as "uncanny space."

Paul Kockelman describes the sieve's functional purposefulness, 
but also its relative fragility in the following terms:

Crucially, sieves have to take on (and not just take in) features of the substances they sieve, if only as 'inverses' of them. A hole in the ground, for example, constitutes a simple sieve: anything with a diameter less than the hole will fall through; anything with a diameter larger than the hole will stay on top. In this way, to sieve a substance, the sieve must often have an (elective) affinity with the substance to be sieved and, in particular, the qualities sieved for-in this case size. In some sense, all sieves are inverses or even shadows of the substances they sort. By necessity, they exhibit a radical kind of intimacy. (Kockelman 2013, 36)

The energy and symbolism of the sieve attaches itself both to the materiality of the sheet-that-sifts (textile, animal hide or other natural substances such as types of grass), and to the action of sorting / sifting / letting through, that is to its functionality and purpose. In the sieve agency and materiality powerfully coincide. The object of use is, as the word itself says, consubstantial with its own materiality, form and purpose: this is a "radical kind of intimacy."

The "intimacy" between function and substance therefore challenges the ancient separation of form and matter in the Aristotelian hylomorphic model in the most "radical" manner. Ingold writes:

To create anything, Aristotle reasoned, you have to bring together form (morphe) and matter (hyle). In the subsequent history of Western thought, this hylomorphic model of creation became ever more deeply embedded. But it also became increasingly unbalanced. Form came to be seen as imposed by an agent with a particular design in mind, while matter, thus rendered passive and inert, became that which was imposed upon. My ultimate aim, however, is ... to overthrow the model itself and to replace it with an ontology that assigns primacy to the processes of formation as against their final products, and to the flows and transformations of materials as against states of matter. (Ingold 2010, 91-92)

Namely that it is a question not of imposing preconceived forms on inert matter but of intervening in the fields of force and currents of material wherein forms are generated. Practitioners, I contend, are wanderers, wayfarers, whose skill lies in their ability to find the grain of the world's becoming and to follow its course while bending it to their evolving purpose. (Ingold 2010, 92)

Hence, when we see the world not as a collection of dead objects that an actor puts to some use, but as a mixed world, we no longer need the polar separation between subject and object and reconciliation between thing and maker / user becomes a given.

The world we inhabit is not made up of subjects and objects, or even of quasi-subjects and quasi-objects. The problem lies not so much in the sub- or the ob-, or in the dichotomy between them, as in the -ject. For the constituents of this world are not already thrown or cast before they can act or be acted upon. They are in the throwing, in the casting. (Ingold 2010, 95)
From this perspective - "in the throwing, in the casting" - the sieve detaches itself as an isolated object, and itself becomes the object of a worldview that reconciles the processual relationship between hand, "thing" and action (sifting).

This makes it possible to think of the sieve as a kinetic and extremely dynamic pact between these parameters. We can now emancipate the sieve from its "objectness" and recognize it as a permeable membrane stretched taut upon the world, the act of making, and the human body itself, advancing and activating their cohesion in a "winnowing," in a "throwing" and in a "casting." Recall James Neil's description:

Holding the sieve in a slanting position, she jerks it up and down for a length of time, blowing across the top of it all the while with great force. In a word, she turns herself into a regular winnowing machine!

This literally makes the sieve a paradigm that counteracts the hylomorphic model of separation. The sieve reconciles and binds.

Tim Ingold goes further still, seeking to show that any creativity and meaning takes place in an interspace: the space "between" matter and form, between substance and technique, between object and subject. Tim Ingold calls this interspace "tectonics" or "binding-something-together" with threads, resulting in knots or more complex patterns and decorative schemes, in short: resulting in surface tectonics. Tectonics have to do with:

On the one hand, the ability to tie knots and to connect them, and on the other hand, by using this connection, to cut through 
them - i. e. in the complementary aspects of weaving and carpentry, textiles and woodwork - and to look for etymological support for his conviction in the word cluster coming from the Greek tekton. [Einerseits der Fähigkeit, Knoten zu formen in Verbindung zu bringen und andererseits mit derjenigen, durch sie hindurchzuschneidendas heißt, in der Komplementarität von Weben und Zimmerhandwerk, Textilien und Holzwerk - und etymologische Unterstützung für seine Überzeugung in dem vom Griechischen Tekton abstammenden Wortcluster zu suchen.] (Ingold 2015, 85)

With the sieve this interspace or tectonics is located on the actual membrane itself. The structure of the sieve's membrane belongs to the spectrum of linking, knotting, open work, thus of textile-related actions and paradigms (Lamb 2005 , 42-45). ${ }^{18}$

Tekton allows the surface to disappear: we see not so much the knot as whatever it is that the knot seals, conceals, covers, opens, and shuts. The net arises at the threshold where the maelstrom and the magical abyss beckon; at the same time both absorbent (implosive) and restrictive (sticky, captive) (Ingold 2007, 53; Gell 1998, 83-90). ${ }^{19}$ The "dissolution of the surface" makes the sieve's net an immaterial field of energy, the amniotic threshold: a selectively permeable gate and transition, as we saw in the fertility rites and cosmogonic associations.

This brings us to the second statement. The sieve is both etymologically and tectonically a net, a grille. With its permeability and its through-visibility, the sieve belongs to the broad anthropological family of the lattice, the lozenge, the grid.
The lozenge is both a motif and a paradigm.

The lozenge is one of the oldest ideograms in the world (Vandenbroeck 2000, 196-199). The longue durée of the net symbol stretches from recurring patterns on objects from the Magdalenian period (Dordogne, 10,000 BC) up until the patterns of embroidery and sewing with its cross-stitching. It is also a core motif in Berber weaving. The lozenge pattern is in fact the endless repetition of the diamond, and shares the notion of "becoming" with this pictogram. The net and the lozenge symbolize creation and the power of reproduction. This notion of potentiality and endless reproduction also becomes attached to the fertility cult and the countless associations of the sieve's birth-giving agency.

In her foundational article on the grid and the lozenge, Rosalind Krauss writes (Krauss 1979, 50-64; see also: Siegert 2015, 97-120):

Now it is in this ambivalence about the import of the grid, an indecision about its connection to matter on the one hand or spirit on the other, that its earliest employers can be seen to be participating in a drama that extended well beyond the domain of art. That drama which took many forms, was staged in many places. ... Therefore, although the grid is certainly not a story, it is a structure, and one, moreover, that allows a contradiction between the values of science and those of spiritualism to maintain themselves within the consciousness of modernism, or rather its unconscious as something repressed. In order to continue its analysis-to assess the very success of the grid's capacities to repress. (Krauss 1979, 54-55)

In short, where Ingold emphasizes tectonics as dissolution and agency with no binary structure, Krauss emphasizes the drama of dualism between spirit and matter. Applying the paradigm of grid / lozenge to the sieve unlocks it as a hermeneutic tool for a scopic regime that needs the structural "support" for a seeing beyond. Although part of the realm of symmetry, the sieve retains the power to un-limit form, to un-compromise structure, and is therefore a Kulturtechnikobjekt that essentially unlocks. This unlocking lies in the capacity to unlimit form, to challenge the scopic regime as a "beyond," continually and powerfully to contest the deeply entrenched dualisms of Western thought, and finally to think the relationship between humanity and environment from the grounds of the permeable membrane as fundamental mediator of the sensorium.

If we link the idea of textility and tectonics to that of the primal force of the net / mesh, the third paradigm appears. The net motif is a "cloth" that is "placed" on the subject, on the body, on the textile, to articulate it as a duplicating membrane. In other words, the tectonic membrane and permeable grille of the sieve as duplicating membrane provides a paradigm for the permeable skin that encloses our body and opens it to the world. The moi-peau or skin-ego was already conceived by Sigmund Freud (1856-1939) and has been developed further by the French psychoanalyst Didier Anzieu (1923-1999) (De Bolle 2010, 7-33; Dorfman 2010, 157-170; Galioto 2013, 188-214). ${ }^{20}$ Freud 
compared the skin-ego to a "mystic writing pad." The child conceives and describes its impressions of the world through its hide barrier (Lafrance 2013, 22). But the skin is a sieve, it can open and contains pores that let through fluid. This makes skin terrifying: its protection and enclosing is not complete. It constantly threatens to "leak" (Hendrick 2013, 56).

Didier Anzieu writes: "The skinego is the original parchment which preserves, like a palimpsest, the erased, scratched-out, written-over, first outlines of an 'original' pre-verbal writing made up of traces upon the skin" (Anzieu 1989; 105). In his earliest work he set out four functions of the skin ego (Anzieu 2010, 477-495): as a containing unifying envelope for the self (1); as a protective barrier for the psyche (2); as a filter of exchanges and surface of inscription for the first traces, a function which makes representation possible (3); and as a mirror of reality (4).

Anzieu's third moi-peau is the sieve skin as a filter that is also a medium. The permeability of the psyche is a precondition of the sieve skin's capacity to be "inscribed" with memories. The sieve skin leaks out to the world and becomes an inscribed membrane and a screen upon that world. Anzieu goes on to define subcategories of the sieve skin. The third moi-peau is a fertile field: it produces hair, fur, and down, and it waters the field with sweat, pheromones, fluids. In just the same way the sieve is made in function of dry and wet, from sifting grains to sieving dairy products, and so the sieve skin is, as it were, also an image of fertile land. ${ }^{21}$
As we have seen, the sieve belongs to the intimate sphere of the woman. The sieve should not go outside; the sieve is the crib; the sieve is the bosom of the earth; the sieve is the amniotic membrane and even the placenta within the womb. In this connection Ernst Fischer introduces a fourth paradigm for the sieve, the "uncanny space" (Fischer 2001, 115-131). He combines sieve as tectonics, as grid and as moi-peau in terms of the woman's position in domestic space.

Architecture introduces a necessary third term, namely 'house' in addition to 'space' and 'home'. ... The house is a fiction made concrete, a perspectival grid that shapes and marks the bodies in houses according to the very ideology of visibility in the name of which it is itself constructed. (Fischer 2001, 123)

The meaning of the sieve, thickened with tectonics, grid and moi-peau, possesses the capacity to be linked to the intimacy and spatial demarcation in the house/household or the notions of Heimlichkeit and secrecy. It is interesting to see that precisely the notion of Heimlichkeit/secrecy derives from secretum, which in turn is derived from segregation, separation.

It seems pertinent in this connection to recall the Latin definition of Heimlichkeit/secrecy as an act of separation, and to note that according to Arnaud Levy, the word originates with the sifting of grain with the purpose to separate the edible from the non-edible, the good from the bad. (Fischer 2001, 124; Levy 1976, 117-130; see also: Vincent 1991, 539-592) The separation is effected by a hole, an orifice, whose function is to allow something to pass or not pass, depending on the relation of the objects shape and size to the shape and size of the hole. Hence, the sifting process allegedly constitutes a metaphorical representation of the anal function. ... The production of Heimlichkeit in the sieve of the house is achieved through a process of excretion: the separation of the homely from the abject. (Fischer 2001, 124)

The voiding function of architecture as "home" arises with Leon Battista Alberti, cited earlier with reference to the metaphor of chastity (Fischer 2001, 124).

Entering the house as spouse is immobilized and secreted through confinement in a hierarchically arranged sequence of private spheres. Within this spatial order, the woman is further sub-divided and ultimately effaced as sexual, desiring subject by being put in her proper place among her husband's possessions. She is declared pleasing for knowing her limits defined by: '... surveillance over a particular space, whether it be the dinner table, the threshold, the church, the fingertips, the bath, the face, the street'. (Fischer 2001, 125; citing Wigley 1992, 338)

The woman vanishes, dissolved into intimate space. Her clothing, her moi-peau can no longer be distinguished from the interior wall coverings on to which the man projects himself (Fischer 2001, 125). ${ }^{22}$

The woman is thus paradoxically not only locked up in the architectural grid, and abjected through the holes of the sieve, she becomes those very holes. In the domestication of space as place, 
its unbroken expanse is punctuated by row upon row of orifices. The art of husbandry in this sense lies in the cultivation of, to use Deleuze and Guattari's term 'a field of anuses'. ${ }^{23}$ (Deleuze and Guattari 1988, 32; Fischer 2001, 125)

Besides the permeable screen, the woman also becomes the dissolving screen. She evaporates into the walls of the house and becomes a writable, definable canvas for male desires and anxieties. In his Della famiglia, Leon Battista Alberti writes that it strikes him as "somewhat demeaning to me to remain shut up in the house among women when I have manly things to do among men," in contrast to "those idle creatures who stay all day among the little females" (Alberti 1969, book III, 2078). Staying indoors apparently has an "unmanning" effect.

The confinement of the interior space is transferred in an optical shrinking process onto the occupant, turning him into a tiny insideout projection of himself: a 'little female' occupied with 'trifles'. The immobilized phallus shrinks and shrivels and wastes away through the sieve's hole, to become a hole itself. (Fischer 2001, 125)

\section{Back to Elizabeth}

In Fischer's approach we now see the sieve as a spatial buffer, a membrane into which female intimacy can empty itself (emission), but into which it can also disappear, as into the hollows of tectonics itself. The sieve's moi-peau then merges with its environment in a final convulsion of complete camouflage. It references the fate of Echo as the only possible antidote to the masculine mirror (On camouflage see: Baert 2016b).

It is from this image of the sieve as the segregation of the woman I would like to return to the portraits of Elizabeth. The sieve was there defined as a filter between the I as woman and the I as queen. The "sieve's penetrability" (although reference is made to the impermeability of Tuccia's sieve) enables her to flow back and forth between both bodies (Goldberg 2010, 43). Elizabeth is after all queen and not simply woman, besides the space of "secrecy" she also inhabits masculine public space. As a consequence she is impenetrable at home, and penetrating outside. She is both camouflage and performance, both Echo and Narcissus.

It is precisely this bipolarity that can be read synecdochally in the portraits' combination of the globe and the sieve. The globe is iconographically masculine and conventional; the sieve is iconographically femininely intimate and controversial. The globe is a fixed and static object, so rather passive and unambivalent, while the sieve is a dynamic, active (ob)-ject (after Ingold), and so elusive and paradoxical. Where the globe is stable, the sieve remains controversial or "cheerfully schizophrenic" (this expression is Krauss's 1979, 60-61) in the way in which it constantly questions fixed values and paradigms. The sieve is in fact ungraspable, slipping through the gaps in the mesh. The globe is a three-dimensional and reflective object, while the sieve is flat and allows the gaze to pass through. The globe thus triggers our sense of sight, while the sieve appeals to touch: the former a "higher" masculine sense, the latter a "lower" feminine sense (more on these in Baert 2013).

Finally, the globe is detached from the body as the separated, uncoupled narcissistic body. The sieve, however, is attached to the moi-peau as an intimate accessory, as prosthesis, as Stella North suggests in her "clothing-ego" (North 2013, 64-89):

The relation of the clothing-ego to the skin ego is, in this instance, one of prosthesis; the clothing-ego can stand in for, reinforce; or even replace the skin ego. ... Clothing goes on facing and interfacing, skin, and vice versa. They are perpetually implying (sic): folding, unfolding and refolding into each other (North 2013, 81). For Anzieu, the prohibition on touching both represents and effects the supersession of the sensory world by the cerebral. It serves an important developmental, and thus social function: 'the prohibition on touch contributes to the differentiation of the orders of reality which remain confused in primary tactile experience. And thus inaugurates the self as separate from its environment. What is prohibited then is the touch between the mental and the corporeal realities confused in primary tactile experience'. (North 2013, 79-80)

\section{Elizabeth is suspended between} globe and sieve: between mirror-projection as queen and canvas-injection as woman. This leaves just one question. Is she a Magdalene who could not touch and only see, and held the vas, the closed and round pitcher as her attribute? Or is she a Veronica who touched the veil and held the screen of the face of all faces, the permeable amnion as her attribute? 
If we could answer these questions, we would finally touch the innermost mystery of womanhood as such.

Nobody, not even the rain, has such small hands. (E.E. Cummings)

There will be time, there will be time/ To prepare a face to meet the faces that you meet. (T.S. Eliot)

\section{Acknowledgements}

The author is grateful to Prof Dr Paul Arblaster and Stephanie Heremans (KU Leuven) for the translations and the editing of this article.

\section{Notes}

1. Although these negotiations came close to success, the queen's Anglican-Protestant supporters were deeply critical of the rapprochement with the Catholic king of France. Furthermore, there were rumors of a relationship with Robert Dudley, Earl of Leicester (Williams 2006, 49-51).

2. "Events from the Dido-Aeneas suggesting the parallel between Aeneas' heroic resistance to Dido's attractions and Elizabeth's dedication to virginity" (Hazard 1976, 32); (Doran 1995; passim); "Leaving the question of the medallions to one side, the pillar itself is not without significance, since it occurs frequently in the iconography as the symbol of Fortitude, Constancy and Chastity" (de Jongh 1975-1976, 89); see also: (King 1985, 64); (de Tervarent 1985, 106-108).

3. Also see: Dionysius of Halicarnassus, in his Greek and Roman Antiquities, 2.69.
4. See my analysis of the attributes of St Verena von Zurzach: the comb and the jar (jug, pitcher). Both objects that can be understood within the feminine pattern of pre-Christian symbols for hygiene (comb) and fertility (the pitcher, the well), christianized by Verena as an exemplum for both Mary and Anna (Baert 2006a, 2006b).

5. Bonoldi identifies Sofonisba as Artemisia, given the botanical detail of the tree that is argued to link her to the poison artemisia absinthium (Bonoldi 2006, n.p. (online)).

6. Inscription right: Alexander Broix, indicating Alessandro Bonvicino of Brescia or Moretto da Brescia.

7. "to purge the seedes/From chaf$f e$ " as Geffrey Whitney put it in his version of the emblem.

8. "Those portraits which might be described as representing the genitive of quality or description, are the most problematic to interpret-partly, as we have seen, because of the contextual ambiguity of the inflection: the ambiguity of relationship between picture and text, often a recherché source; the ambiguity intended by a political subject, patron, artist, or some combination of these. Such pictures were probably as difficult to interpret for Elizabethans as for us" (Hazard 1990, 79).

9. The poem On Monsieur's Departure might refer to the leaving of Francis, Duke of Alençon, in 1582, or to her concealed love for the Earl of Leicester (Teague 1987, 536).

10. Moreover, the "net" and in particular the "fishing net" also underlie the development of lace. There is a sense of this in legends about the origins of lace in Burano, Veneto (Harrison 1989).

11. See also: the sieve in the Verbeeck's Peasant Wedding. Bilbao, Museo de Bellas Artes (Vandenbroeck 1984, 98; on folk customs Marmorstein 1922, 235); on swinging in folk belief (Fehrle 1916-17, 547-551).

12. Sifting is the final stage in the rural process of grain consumption. First is threshing. "Essential to threshing was a 'threshing floor', a flat area of hard dirt or rock on which freshly harvested wheat could be piled. Quite a few verses, from Genesis to the New Testament, mention threshing floors, which makes sense because grain was so essential to life. ... Winnowing was the process that separated the mixed up pile of grain, stalk, and husk so that the edible grain could be sifted and eaten. To winnow the grain, the farmer scooped up the pieces of the crop he had just threshed and threw it all up into the air. The wind blew the light pieces of stalk to the side, while the grain, which was both heavier and roundish, fell almost straight back down. Thus, over time, the threshing floor was covered with three quite distinct piles of material. The kernels of grain fell almost straight down or were not blown far at all. The larger pieces of stalk, or 'straw', had blown a little ways off to the side, and the small pieces of stalk, called the 'chaff', had blown even further away" (http://www.truthortradition. com/articles/threshing-win- 
nowing-sieving-separating-thegood-from-the-bad).

13. Blum 1981 refers in note 28 to examples in New York, Pierpont Morgan Library, M. 55, Vita et Miracllla Sancti Benedicti, fol. $2 \mathrm{v}$, a manuscript dating to the first decade of the fourteenth century, in which the capisterium resembles a trough.

14. See the Wordsworth Dictionary of Phrase and Fable: "sieve and shears" on divination with shear points along the sieve's frame (Brewer 2001, 999).

15. "The motif certainly survived into the nineteenth century, appearing, for instance, in Halliwell's 1849 Nursery Rhymes and Tales in a nonsense tale which begins, "I saddled my sow with a sieve full of buttermilk and leaped nine miles beyond the moon into the land of Temperance"” (Jones 1989, 205).

16. I return (see note 4) to Verena von Zurzach. The comb, like the sieve, has a purifying function: it removes dirt and lice. As an object of cleanliness, it refers to Verena's virginity. But the specifity and the capacity of the object-its possession of "teeth"-provide a primal association with the female intimacy of giving birth: "the vagina dentata" as a fantasy of the womb. As we shall see below, the sieve's ability to drip, its permeability, make it an image of the mniotic sac or of the placenta (Baert 2006a, 9-25, 2006b, 35-62).

17. Circular motions are "read" in nature: Ruach, wind, and thus "enthusiasm" descends into the dancing body (see the first chapter of Baert 2016a).
The process of winnowing (see above and note 12 , and below under Textilities) ties sorting to the natural power of wind and air movements.

18. (Lamb 2005, 42-45) refers to hide sieve weavers in Tunis. They make the sieves on the spot in little stalls on the market. A wooden frame $10 \mathrm{~cm}$ wide and about $96 \mathrm{~cm}$ long is bent to produce a round holder, over which the skin is stretched.

19. In his fascinating work Lines: $A$ Brief History, Tim Ingold sets out in search of the origin and the effects of lines in our interaction with the world. In relation to the knot and, by extension, the notion of connecting, tying or braiding a cord or a thread, the author refers to an association with meshes, with lacework and with the labyrinth, all of which used to be considered to possess apotropaic qualities (Ingold 2007).

20. "The first schizophrenic evidence is that the surface has split open. ... bodies have no surface. The primary aspect of the schizophrenic body is that it is a sort of body-sieve. ... Other bodies always penetrate our body and coexist with its parts" (De Bolle 2010, 24); "Our sensorium is both screen (energy, quantity) and sieve (qualitative characteristics or stimuli that Freud calls periods)" (Dorfman 2010, 160); "The buffer between me and the other is the sieve (Lacan)" (Galioto 2013, 198).

21. Other functions of the skin-ego are storage of fats as an image of memory, the function of production (hair, nails), emission for example sweat and phero- mones. These are the skin-ego's defence mechanisms (Anzieu 2010, 488-489).

22. The dresses match with white and unadorned walls (after Alberti) as blank surfaces on which the man projects himself.

23. See too the highly recognizable grille that separates priest and penitent in the confessional. The grille (or curtain) ensures anonymity, but from the Fischer-Deleuze perspective this 'sieve' of separation, secrecy, can also be read like the dissolving wall of anuses (Deleuze and Guattari 1988, 32; Fischer 2001, 125). See also on the grid/ net/lace surface as dissolution surface in the paradigm by Tim Ingold.

\section{References}

Abrahamian, Levon. 2007. "The Chained Hero: The Cave and the Labyrinth." Iran \& the Caucasus 11 (1): 89-99.

Adams, Douglas Q. 1997a. "art. Clean." In Encyclopedia of IndoEuropean Culture, edited by James P. Mallory and Douglas Q. Adams, 108-109. London: Fitzroy Dearborn.

Adams, Douglas Q. 1997b. “art. Sieve." In Encyclopedia of IndoEuropean Culture, edited by James P. Mallory and Douglas Q. Adams, 518. London: Fitzroy Dearborn.

Adler, Doris. 1978. "The Riddle of the Sieve. The Siena Portrait of Queen Elizabeth." Renaissance Papers: 1-10.

Alberti, Leon Battista. 1969. Family in Renaissance Florence, edited and translated by Renée N. Watkins. Columbia SC: University of South Carolina. 
Anzieu, Didier. 1989. The Skin Ego: A Psychoanalytic Approach to the Self. New Haven, CT: Yale University Press.

Anzieu, Didier. 2010. "Functions of the Skin Ego." In Reading French Psychoanalysis, edited by Dana Birksted-Breen, Sara Flanders and Alain Gibeault, 477-495. LondonNew York: Routledge.

Baert, Barbara. 2006a. "Jar and Comb. Verena of Zurzach as an Example for the Limits and the Possibilities in Iconology." In Antwerp Royal Museum Annual, 9-25. Antwerp: Exselsior.

Baert, Barbara. 2006b. "Wasserkrug und Kamm. Die Darstellung der Verena von Zurzach, ein Beispiel für neue Tendenzen in der ikonologischen Methodik." [Jar and Comb. Verena of Zurzach as an Example for the Limits and the Possibilities in Iconology.] Österreichische Zeitschrift für Volkskunde [Austrian Journal of Folklore] 60 (109): 35-62.

Baert, Barbara. 2013. "An Odour, a Taste, a Touch. Impossible to Describe. Noli me tangere and the Senses." In Religion and the Senses in Early Modern Europe (Intersections. Interdisciplinary Studies in Early Modern Culture, 26), edited by Wietse de Boer and Christine Goettler, 111-151. Leiden: Brill.

Baert, Barbara. 2016a. Pneuma and the Visual Arts in the Middle Ages and Early Modernity, (Art \& Religion, 5). Leuven-Walpole: Peeters.

Baert, Barbara. 2016b. In Response to Echo, (Studies in Iconology, 6). Leuven-Walpole: Peeters.
Baskins, Cristelle. 1999. "Il trionfo della pudicizia: Menacing Virgins in Italian Renaissance Domestic Painting." In Menacing Virgins: Representing Virginity in the Middle Ages and Renaissance, edited by Kathleen C. Kelly and Marina Leslie, 15-25. Newark, DE: University of Delaware.

Bayer, Andrea, ed. 2008. Art and Love in Renaissance Italy, (exh. cat.). New York: The Metropolitan Museum of Art.

Blum, Pamela Z. 1981. "The Saint Benedict Cycle on the Capitals of the Crypt at Saint-Denis." Gesta (Essays in Honor of Harry Bober) 20 (1): $73-87$.

Bonoldi, Lorenzo 2006. "Sofonisba o Artemisia? Ossservazioni su un monocromo di Andrea Mantegna." Engramma-Saggi 52: n.p. (online).

Brewer, Ebenezer C. 2001. The Wordsworth Dictionary of Phrase and Fable. Hertfordshire: Wordsworth.

Cerasano, Susan P., and Marion Wynne-Davies. 1992. "From Myself My Other Self I Turned." In Gloriana's Face: Women, Public and Private in the English Renaissance, edited by Susan P. Cerasano and Marion Wynne-Davies, 1-23. Detroit, MI: Wayne State University Press.

Chevalier, Jean, and Alain Gheerbrant. 1982. "art. Tamis.” [art. Sieve] In Dictionnaire des Symboles. [Dictionary of Symbols], 921-922. Paris: Robert Laffont.

Cirlot, Juan E. 2001. "art. Sieve/ Cribble." In A Dictionary of Symbols, 296. London: Taylor \& Francis.
Connolly, Annaliese, and Lisa Hopkins, eds. 2007. Goddesses and Queens: The Iconography of Elizabeth. Manchester, NH: Manchester University Press.

De Bolle, Leen, ed. 2010. Desire and Schizofrenian in Deleuze and Psychoanalysis. Philosophical Essays on Deleuze's Debate with Psychoanalysis. Leuven: Leuven University Press.

de Jongh, Eddy. 1975-76. "Pearls of Virtue and Pearls of Vice." Simiolus: Netherlands Quarterly for the History of Art 8 (2): 69-97.

de Tervarent, Guy. 1985. Attributs et symboles dans l'art profane, 1450 160o, vol. 1. Geneva: Droz.

Deleuze, Gilles, and Felix Guattari. 1988. A Thousand Plateaus. London: Bloomsbury.

Deleuze, Gilles. 1990. The Logic of Sense, translated by Marc Lester. New York: Columbia University Press.

Doran, Susan. 1995. "Juno versus Diana. The Treatment of Elizabeth l's Marriage in Plays and Entertainments, 1561-1581." The Historical Journal 38 (2): 257-274.

Dorfman, Eran. 2010. "Foucault versus Freud On Sexuality and the Unconscious." In Sexuality and Psychoanalysis. Philosophical Criticisms, edited by Jens de Vleminck and Eran Dorfman, 157-170. Leuven: Leuven University Press.

Du Cange, Carolus du Fresne. 1954. Glossarium mediae et infimae Latinitatis [Glossary of Medieval and Late Latin], vol. II, edited by Léopold Favre. Graz: Akademische Druck-U. Verlag-Sanstalt. 
Dyson, Robert W., ed. and trans. 1998. Augustine, The City of God against the Pagans. Cambridge: Cambridge University Press.

Eckstein, Friedrich. 1936. "art. Sieb." [art. Sieve.] In Handwörterbuch des deutschen Aberglaubens [Dictionary of German Superstition], vol. II, 1662-1701. Berlin: Walter de Gruyter.

Erickson, Elisabeth P., and Clark Hulse, eds. 2000. Early Modern Visual Culture. Representation, Race and Empire in Renaissance England. Philadelphia, PA: Pennsylvania University Press.

Fehrle, Eugen. 1916-17. “Das Sieb im Volksglauben.” [The Sieve in Popular Culture.] Archiv für Religionswissenschaft [Archive for Religion Studies] 19: 547-551.

Fischer, Ernst. 2001. "Writing Home. Postmodern Melancholia and the Uncanny Space of Living-room Theater." In Psychoanalysis and Performance, edited by Patrick Campbell and Adrian Kear, 115-131. London: Routledge.

Galioto, Erika D. 2013. "Split-Skin. Adolescent Cutters and the Other." In Skin, Culture, and Psychoanalysis, edited by Sheila L. Cavanagh, Angela Failler and Rachel A. J. Hurst, 188-214. London: Palgrave.

Gell, Alfred. 1998. Art and Agency. An Anthropological Theory. London: Clarendon Press.

Goldberg, Jonathan. 2010. Sodometries. Renaissance Texts, Modern Sexualities. New York: Fordham University Press.

Harrison, Barbara G. 1989. Italian Days. New York: Atlantic Monthly Press.
Hart, Christophe, ed. 2008. Heroines and Heroes. Symbolism, Embodiment, Narratives \& Identities. Kingswinford: Midrash Press.

Hazard, Mary E. 1976. “An Essay to Amplify 'Ornament.' Some Renaissance Theory and Practice." Studies in English Literature, 1500190016 (1): 15-32.

Hazard, Mary E. 1990. “The Case for 'Case' in Reading Elizabethan Portraits." Mosaic 23: 61-88.

Hendrick, Yves. 2013. Facts and Theories about Psychoanalysis. London-New York: Routledge.

Ilan, Tal. 2003. "Dance and Gender in Ancient Jewish Sources." Near Eastern Archaeology (Dance in the Ancient World) 66 (3): 135-136.

Ingold, Tim. 2007. Lines. A Brief History. London: Routledge.

Ingold, Tim. 2010. "The Textility of Making." Cambridge Journal of Economics 34: 91-102.

Ingold, Tim. 2015. "Bauen Knoten

Verbinden.” [Building Knotting Connecting.] Zeitschrift für Medienund Kulturforschung [Journal of Media and Cultural Research] 6 (1): 81-100.

Jones, Malcolm. 1989. "Folklore Motifs in Late Medieval Art I: Proverbial Follies and Impossibilities." Folklore 100 (2): 201-217.

King, Helen. 1986. "Sacrificial Blood: The Role of Amnion in Ancient Gynecology." Helios 13 (2): 117-126.

King, John N. 1985. “The Godly Woman in Elizabethan Iconography." The Renaissance Quarterly 38 (1): 41-84.
Knapp, Bettina L. 1990. “Yizhar’s 'Midnight Convoy'. Wheels, Circles, Eyes: The Dynamics of the Feminine Principle as Eros/Logos." Modern Language Studies 20 (3): 58-66.

Kockelman, Paul. 2013. "The Anthropology of an Equation: Sieves, Spam Filters, Agentive Algorithms, and Ontologies of Transformation." Journal of Etnographic Theory 3 (3): 33-61.

Krauss, Rosalind. 1979. “Grids.” October 9: 50-64.

Kürti, László. 2007. “Language, Symbol and Dance. An Analysis of Historicity in Movement and Meaning." Shaman. Journal of the International Society for Shamanistic Research 2 (1-2): 23-82.

Lafrance, Marc. 2013. "From the Skin Ego to the Psychic Envelope: An Introduction to the Work of Didier Anzieu." In Skin, Culture, and Psychoanalysis, edited by Sheila L. Cavanagh, Angela Failler, and Rachel A. J. Hurst, 16-44. London: Palgrave.

Lamb, Venice. 2005. Looms Past and Present: Around the Mediterranean and Elsewhere. Hertingfordbury: Roxford Books.

Levy, Arnaud. 1976. "Evaluation etymologique et semantique du mot 'secret'." Nouvelle revue de psychanalyse 14: 117-130.

Lilek, Emilijan. 1896. Volksglaube und volksthümlicher cultus in Bosnien und der Hercegovina. Vienna: C. Gerold.

Lurker, Manfred. 1991. "art. Gefäss.” [Font.] In Wörterbuch der Symbolik. [Dictionary of Symbolism], edited by Manfred Lurker, 232-233. Stuttgart: Kröner Verlag. 
Makilam. 2007. The Magical Life of Berber Women in Kabylia. New York: Peter Lang.

Marmorstein, Arthur. 1922. "Das Sieb im Volksglauben.” [The Sieve in Popular Culture.] Archiv für Religionswissenschaft [Archive for Religion Studies] 21: 235.

Miziolek, Jerzy. 2001. "Exempla di Giustizia. Tre tavole di cassone di Alvise Donati." [Exempla of Justice. Three panels of the cassone of Alvise Donati.] Arte Lombarda [Lombard Art] 2: 72-88.

Montrose, Louis. 2006. The Subject of Elizabeth. Authority, Gender, and Representation. Chicago, IL: University of Chicago Press.

Moricca, Umberto, ed. 1924. Gregorii Magni Dialogi. (Fonti per la storia d'Italia, 57). [Gregory the Great's Dialogues. Sources for the History of Italy]. Rome: Senato.

Neil, James. c. 1915. Peeps Into Palestine. Strange Scenes in the Unchanging Land Illustrative of the Ever-Living Book. London: Stanley Martin.

Neumann, Erich. 1957. Die Grosse Mutter. Der Archetyp des grossen Weiblichen. Darmstadt: Wissenschaftliche Buchgesellschaft. North, Stella. 2013. "The Surfacing of the Self. The Clothing-Ego.” In Skin, Culture, and Psychoanalysis, edited by Sheila L. Cavanagh, Angela Failler, and Rachel A. J. Hurst, 64-89. London: Palgrave.

Paster, Gail K. 1993. The Body Embarrassed. Drama and the Disciples of Shame in Early Modern England. Ithaca, NY: Cornell.

Patai, Raphael. 1983. On Jewish Folklore. Detroit, MI: Wayne State University Press.
Philippa, Marlies, et al. 2003-09. Etymologisch Woordenboek van het Nederlands. Amsterdam: Amsterdam University Press.

Popov, Rachko. 1989. Butterfly and Gherman. Sofia: Septemvri State Publishing House.

Ritner, Robert K. 1985. "Anubis and the Lunar Disc." The Journal of Egyptian Archaeology 71: 149-155.

Róheim, Géza. 1951. Psychoanalysis and the Social Sciences. vol. 3. New York: National Universities Press.

Shackleton Bailey, David R., ed. and trans. 2000. "Libri IX, 8.1.5." In Valerius Maximus, Memorable doings and sayings, vol. 2, (Loeb Classical Library, 492), 193. Cambridge, MA: Harvard University Press.

Siegert, Bernhard. 2015. "(Not) in Place: The Grid, or, Cultural Techniques of Ruling Spaces." In Cultural Techniques. Grids, Filters, Doors, and Other Articulations of the Real, (Meaning Systems, 22), translated by Geoffrey WinthropYoung, 97-120. New York: Fordham University Press.

Siegert, Bernhard. 2015. Cultural Techniques. Grids, Filters, Doors, and Other Articulations of the Real, (Meaning Systems, 22), translated by Geoffrey Winthrop-Young. New York: Fordham University Press.

Strong, Roy. 1987. Gloriana. The Portraits of Queen Elizabeth I. London: Thames \& Hudson.

Teague, Frances. 1987. "Elizabeth I: Queen of England.” In Women Writers of the Renaissance and Reformation, edited by Katharina M. Wilson, 522-547. Athens GA: University of Georgia Press.
Tuve, Rosemond. 1963. "Notes on the Virtues and Vices." The Journal of the Warburg and Courtauld Institutes 26 (3-4): 264-303.

Vandenbroeck, Paul. 1984. “Verbeeck's Peasant Weddings: A Study of Iconography and Social Function." Simiolus. Netherlands Quarterly for the History of Art 14 (2): 79-124.

Vandenbroeck, Paul. 2000. Azetta: Berbervrouwen en hun kunst. Ghent: Ludion.

Vincent, Gerard. 1991. "The Secrets Of History And The Riddle Of Identity." In A History of Private Life, vol. 5, edited by Antoine Prost and Gérard Vincent, 539-592. Cambridge-London: Harvard University Press.

Whitney, Geffrey. 1586. Choice of Emblemes. Leiden: Plantin Press.

Wigley, Mark. 1992. "Untitled: The Housing of Gender." In Sexuality and Space, edited by Beatriz Colomina, 327-389. New York: Princeton Architectural Press.

Williams, Deanne. 2006. "Dido, Queen of England." English Literature History 73 (1): 31-59.

Ziegler, Georgianna. 1992.

"Penelope and the Politics of Woman's Place in the Renaissance." In Gloriana's Face: Women, Public and Private, in the English Renaissance, edited by Susan P. Cerasano and Marion Wynne-Davies, 25-47. Detroit, MI: Wayne State University Press.

Zysk, Kenneth G. 1985. "Religious Healing in the Veda." Transactions of the American Philosophical Society, New Series 75 (7): 1-311. 